VISION: Journal of Indian Taxation Volume 4, Issue 1, January-June 2017, pp. 1-18 doi: 10.17492/vision.v4i01.9990

\title{
Federal Finance in India: An Analysis of Discretionary Transfers
}

\author{
Chittaranjan Nayak* and Priyabrata Satpathy**
}

\begin{abstract}
The essence of federalism lies in proper division of powers and functions among various levels of government to ensure adequate resources for their functioning. Although a formula-based practice has been mandated by the Indian Constitution through the setting up of the Finance Commission of India, there are several breaks in the practice. Some of the Central transfers are formula-based but there is considerable discretion in allocating other classes of transfers. In the era of Coalition politics there has been increasing disquiet, especially by the states ruled by opposition parties about alleged partisan behaviour by the Centre in the allocation of discretionary transfers. The present paper makes an attempt to examine the level, composition and disparity in per capita discretionary transfers from the Centre to the states; and explore the determinants of discretionary transfers. Two time points, viz. 2001-02 and 2011-12 are considered since the study has used census data for some variable. The empirical results show that there is significant diversity in the level of discretionary transfers to states. However, the disparity is not due to political factors. The states with higher fiscal deficit have got more discretionary transfers than the states having lesser deficit. Special category states get higher discretionary transfers as it is inherent in the structure of such transfers.
\end{abstract}

Keywords: Federal finance; Discretionary transfers; Fiscal balance; Finance Commission; Political determinants.

\subsection{Introduction}

Federal finance is basically about the division of resources and functions between different levels of governments. India represents a typical case of a federation with a constitutional demarcation of functions and finances between the Union and the states. The Seventh Schedule of the Indian Constitution has arranged for a clear division of

*Corresponding author; Assistant Professor, Department of Economics, Ravenshaw University, Cuttack, Odisha, India. (Email id: chittaranjan.ru@gmail.com)

**Ph. D. Research Scholar, Department of Economics, Ravenshaw University, Cuttack, Odisha, India. (Email id:psatpathy.satpathy@gmail.com) 
2 | VISION: Journal of Indian Taxation, Volume 4, Issue 1, January-June 2017

financial powers and expenditure responsibilities between the Centre and state governments. The Constitution of India has also made a number of enabling provisions for fiscal transfers like the formation of Finance Commission for formula-based transfers from the Centre to states. A major reason behind fiscal transfers is to tone down the fiscal imbalances resulted due to the mismatch in the revenue powers and expenditure responsibilities of the Union vis-à-vis the state governments. However, rationalisation of the transfer system and restoration of fiscal balance in the states has always been a controversial issue in a federal system. One such issue is the existence of multiple channels of transfers which are not formulaic but the Centre has a lot of discretion to transmit resources to the states.

There are three channels of transfer of finance from Centre to states. They are:

(i) Finance Commission which recommends the tax devolution and grants-in-aid to states;

(ii) Planning Commission ${ }^{1}$ which stipulates (a) Normal central assistance comprising untied assistance for the annual plans of states based on the Gadgil-Mukherjee formula; (b) Additional Central Assistance for specific-purpose schemes and transfers; (c) Special Central Assistance is provided for special projects or programmes like Western Ghats Development Programme (WGDP), Border Areas Development Programme, etc., and (d) Special Plan Assistance provided to the Special Category States for funding of projects identified by the States that are not covered by any central scheme and for nonrecurrent expenditure of a developmental nature,

(iii) Union Ministries which run a number of Central Plan Schemes and Centrally Sponsored Schemes, which are conditional upon the implementation of specified schemes and programmes.

The Finance Commission is a constitutional body and the key institution responsible for dealing with fiscal imbalances between the Centre and states, as well as among the states. The Articles 270, 275, 282, and 283 of the Constitution have delineated the boundary of the Centre and the states relating to tax sharing, resource allocation and grants-in- aid. In addition to the transfers as per the Finance Commission recommendations, the erstwhile Planning Commission was giving grants and loans for implementing development plans. As there is no specific provision in the Constitution for plan transfers, the central government channelises them under the miscellaneous head as indicated by Article 282. Furthermore, various ministries give grants to their counterparts in the states for specified projects either wholly funded by the Centre (central sector projects) or requiring the states to share a proportion of the cost (Centrally Sponsored Schemes). In federal finance terminology, more often than not, transfers 
except tax devolution, grants in aid and Normal Central Assistance, are known as discretionary transfers ${ }^{2}$.

Discretionary transfers are not guided by any predetermined formula. So it always leaves wide space for speculation that these are guided by wishes of the political parties in power. Various ministries give assistance under various central sector and centrally sponsored schemes which might be fanciful and politically biased. This constitutes roughly one third of the aggregate budgetary transfers from Centre to the states. Very often allegations are levelled against the Centre for being partisan and apathetic to the interests of states ruled by opposition parties. Scholars have also taken interest in understanding the issue that: (i) if coalition politics has brought political manoeuvring, bargaining and lobbying by the states to get a larger pie of this transfer, and (ii) if the central government has become opportunistic to use such transfers as a tactical instrument while disbursing funds to the states.

Under this backdrop, this paper attempts to focus on the volume, pattern and determinants of central discretionary transfers to sub-national governments by taking into consideration the political economy features along with some other factors. The remainder of the paper is organised as follows: Section 2 presents a review of literature. Data and methods for this study are explained in Section 3; Section 4 analyses the results, and Section 5 concludes.

\subsection{Review of Literature}

The traditional literature on fiscal federalism reveals that transfers are mainly determined by economic rationales of efficiency and equity (Buchanan, 1950; Oates, 1972; and Gramlich, 1977). The equity and efficiency debate on centre-state fiscal relationship has gone up due to difference in fiscal capacities between union government and state governments or even among state governments. The difference in fiscal capacity is measured by the disparity in taxation capacity and expenditure responsibilities of the respective government. Given this system of taxation and expenditure assignment, the states are unable to match their expenditures to their revenues. This is generally known as the vertical fiscal imbalance. Apart from vertical imbalances, the states also face the problem of a horizontal disparity because different States face different degrees of inadequacy and this is because there is no uniform tax collection. Due to such mismatch, the Centre is required to allocate funds to overcome this inadequacy. Despite the increase in revenue at the state level, dependence has risen even further. This is because while revenue has been experiencing a steady increase, it has been unable to keep up with the faster rising expenditure. 
Only a handful of research works is available on discretionary transfers. The studies of Lindbeck and Weibull (1987) and Dixit and Londregan (1996) emphasise the presence of an asymmetry in the allocation of discretionary transfers due to incumbency, specifically the role of incumbent party is highlighted whereas the role of opposition party is suppressed.

Further Dasgupta, Dhillon, and Dutta (2004) constructed an explicit model by extending the Dixit and Londregan (1996) model to incorporate inter-governmental transfers. Their work provided strong support for the influence of political variables on discretionary transfers. The true spirit of federal fiscal transfer in India breaks when political intervention goes beyond expectation. Sometimes nature of political parties in power at Centre as well as states does intervene on Centre-state fiscal transfers. Another study by Rao and Singh (2000), shows Centre's discretion depends on economic importance of the states, measured by the state domestic product, as well as the political importance of the states, measured by their importance in the ruling coalition and both determines the composition of per capita transfer to the states. This is broadly consistent with the Riker (1975) view of federalism as "a constitutional bargain among politicians", even though the Indian system is not the result of an explicit joining of its constituent parts. Singh and Vasishtha (2004) have extended the work of Rao and Singh (2000) with an additional political variable that is 'lobbying power' variable based on representation of different states in the ministerial cabinet. Their findings suggest that states with greater bargaining power, as proxied by political variables, tend to receive larger per capita transfers.

Khemani (2003) in his study shows what role do political parties play in mediating this intergovernmental bargaining over the allocation of national resources. This means whether the single party ruling government and its affiliation at state have higher fiscal transfer or national government consists of multiparty with coalition of political parties do states ruled by coalition partners bargain for higher transfer. The paper reveals that those state governments that belong to the same party as that leading the national government get higher transfer; correspondingly, states governed by rival political parties have lower transfer, even if these parties are members of a coalition government at the Centre. Even though such partisan effect of India's fiscal transfer is not mandated by our Constitution, still it is quite alarming in recent federal fiscal transfer. So the political biasness among Centre state fiscal transfer may not justify the equity and efficiency criteria of resource allocation.

Arulampalam et al.(2009) have constructed a model of redistributive politics where the Central government is opportunistic and uses its discretion to make transfers to state governments on the basis of political considerations. They have considered a 
data set of 14 Indian states from 1974-75 to 1996-97 and two political variables namely swing and alignment in their analysis of discretionary transfers. They found that a state which is both aligned and swing in the last State election is estimated to receive higher transfers than a state which is unaligned and non-swing.

A study by Biswas et al. (2009) observes that Centre-state funds transfer systems in India have a political bargaining aspect that goes beyond the normative considerations. The impact of political lobbying is greater if the Centre is ruled by coalition government with no absolute majority. In order to quantify the amount of lobby a state does at Centre depends on a variety of factors like ministerial representation in the council of ministers, constituent states' political alignment with the Centre, coalition government etc. The study attempts to construct a number of political features that make an effort on part of the constituent states to pull central funds toward their end. But the very complex structural set-up of India as a federation makes it difficult to construct suitable variables to examine how political incentives influence economic decisions. According to them the theoretical explanation of the study is drawn from distributive politics and the two basic model- cores and swing i.e. vote maximizing parties allocated distributive benefits to their core voters. The major findings reveal that there is a significant positive relationship between political variables and discretionary disbursement and parties belonging to the ruling coalition have an advantage over the counter parts` in pulling central funds.

In the light of these facts, it would be interesting to investigate whether these political factors affect the expenditure allocation of the Indian states or not. A recent study has pointed out that "due to competitive politics and coalition government, governments normally resort to play redistributive tactics throughout their tenure of governance" (Dash and Raja, 2012). Further the study observes that the "years just before election are no more treated differently". Panda (2016) in a recent study finds that transfers are higher to the states whose fiscal capacity is low and the unit cost of providing public services is high. The study also observes that political variables do not determine discretionary transfers as advocated by some other studies.

Thus a brief review of literature observes disagreement in the literature regarding the determinants of discretionary transfers and their relative effectiveness. Unlike the previous studies, the present paper attempts to examine the level, composition and disparity in the per capita discretionary transfers from the Centre to the states. An attempt is also made to explore the determinants of per capita discretionary transfer to states. 
6 | VISION: Journal of Indian Taxation, Volume 4, Issue 1, January-June 2017

\subsection{Data and Methodology}

The present paper is based on secondary data collected from different sources. Data on fiscal transfers from the Centre to the states are compiled from the Annual Studies of State Finances (ASSF) published by Reserve Bank of India, Economic Surveys and Public Finance Statistics annual issues on details of finances of state governments. The two census years 2001 and 2011 are considered for a comparison. One of the basic guiding principles of transfer is (horizontal and vertical) equity. The core of this principle is that citizen should not be discriminated on any ground. So we have taken the state-wise transfer of discretionary transfers per capita is considered as the dependent variable for this study. In addition, the variables in this paper are considered in per capita terms wherever feasible. We have computed state's own share in total revenue (SOR) and fiscal balance as percentage of GSDP to understand the tax capacity versus expenditure liabilities of the state. GSDP per capita is considered as a measure of economic status of states. Population density is also considered as a possible determinant of discretionary transfer. The variables are detailed in Table 1.

Table 1: Abbreviation/ Definition of the Variables for the Study

\begin{tabular}{|l|l|c|l|}
\hline $\begin{array}{l}\text { S. } \\
\text { No. }\end{array}$ & Variable & Abbreviation & Definition \\
\hline 1 & $\begin{array}{l}\text { State population } \\
\text { density }\end{array}$ & SPD & $\begin{array}{l}\text { State population density is obtained by dividing } \\
\text { total population by total area of the state. }\end{array}$ \\
\hline 2 & GSDP Per capita & GDPC & $\begin{array}{l}\text { Gross state domestic product per capita is } \\
\text { obtained by dividing total GSDP of state by } \\
\text { population of the state. }\end{array}$ \\
\hline 3 & $\begin{array}{l}\text { State fiscal balance } \\
\text { percentage }\end{array}$ & FB & State fiscal balance as percentage of GSDP. \\
\hline 4 & $\begin{array}{l}\text { Share of own } \\
\text { revenue }\end{array}$ & SOR & $\begin{array}{l}\text { Share of own revenue in total revenue of the } \\
\text { state from all sources including transfers }\end{array}$ \\
\hline 5 & $\begin{array}{l}\text { Bargaining power } \\
\text { The number of MPs elected to LokSabha from } \\
\text { the state is considered as a proxy of bargaining } \\
\text { power of the state. }\end{array}$ \\
\hline 6 & $\begin{array}{l}\text { Political party } \\
\text { dummy }\end{array}$ & BGP & $\begin{array}{l}\text { Political party dummy is taken 1 as same party } \\
\text { or coalition partner is ruling at Centre as well } \\
\text { as state or 0- otherwise }\end{array}$ \\
\hline 7 & $\begin{array}{l}\text { State category } \\
\text { 1-Special Cateory States (SCS), 0-Non Special } \\
\text { Category States (NSCS) }\end{array}$ \\
\hline 8 & $\begin{array}{l}\text { Discretionary } \\
\text { transfer per capita }\end{array}$ & CAT & $\begin{array}{l}\text { Per capita Discretionary transfer is total } \\
\text { discretionary transfer to state divided by total } \\
\text { population of the state. }\end{array}$ \\
\hline
\end{tabular}


The economic variables include GSDP per capita, population density, fiscal balance (deficit/surplus) as percentage of GSDP, and State's share of own revenue in total revenue. The political variables for the study are the political party dummy and the number of MPs from the state in Lok Sabha. State category, i.e. SCS or NSCS, is taken as a basis of classification which has both economic and political underpinnings. All these variables are considered for two census years 2001 and 2011. After examining the descriptive statistics of the variables, the study has done an ANOVA analysis of the variables for SCS versus NSCS categories of states. Thereafter the technique of regression by backward elimination is attempted to explore the variables which are significant. The procedure is repeated for the same set of variables for both the years 2001 and 2011, and analysis is made accordingly.

\subsection{Results and Discussion}

It may be noted that the Indian Constitution does not include any provision for categorisation of any state as an SCS or an NSCS. But, recognising that some regions in the country were historically disadvantaged in contrast to others, Central Plan Assistance to SCS states has been granted in the past by the National Development Council (NDC), a body of the erstwhile Planning Commission. The NDC granted this status based on a number of features of the states which included: hilly and difficult terrain, low population density or the presence of sizeable tribal population, strategic location along international borders, economic and infrastructural backwardness and non-viable nature of the state finances.

The SCS states used to receive block grants based on the Gadgil-Mukherjee formula, which effectively allowed for nearly 30 per cent of the Total Central Assistance in 2009-10. Following the constitution of the NITI Aayog (after the dissolution of the Planning Commission) and the recommendations of the Fourteenth Finance Commission (FFC), central plan assistance to SCS states has been subsumed in an increased devolution of the divisible pool to all states (from $32 \%$ in the 13th FC recommendations to $42 \%$ ) and do not any longer appear in plan expenditure. The FFC also recommended variables such as "forest cover" to be included in devolution, with a weightage of 7.5 in the criteria and which could benefit the north-eastern states that were previously given SCS assistance. Besides, assistance to Centrally Sponsored Schemes for SCS states is given with $90 \%$ central share and $10 \%$ state share. Table 2 makes a comparison between SCS and NSCS states in all the variables as abbreviated in Table 1.The differences between the SCS and NSCS states are quite discernible in Table 2.There is a huge gap in population density, bargaining power and state's own share of revenue in the total 
8 | VISION: Journal of Indian Taxation, Volume 4, Issue 1, January-June 2017

revenue. There is also a significant difference in the per capita discretionary transfer. The SCSs get an average transfer of Rs. 470 per head as compared to just Rs. 99 in case of NSCS.

Table 2: Profile of SCS versus NSCS States in 2001

\begin{tabular}{|c|c|c|c|c|c|c|c|c|c|}
\hline & \multirow[t]{2}{*}{$\mathbf{N}$} & \multirow[t]{2}{*}{ Mean } & \multirow{2}{*}{$\begin{array}{c}\text { Std. } \\
\text { Deviation }\end{array}$} & \multirow{2}{*}{$\begin{array}{c}\text { Std. } \\
\text { Error }\end{array}$} & \multicolumn{2}{|c|}{$95 \%$ C I Mean } & \multirow[t]{2}{*}{ Minimum } & \multirow[t]{2}{*}{ Maximum } \\
\hline & & & & & & $\begin{array}{l}\text { Lower } \\
\text { Bound }\end{array}$ & $\begin{array}{l}\text { Upper } \\
\text { Bound }\end{array}$ & & \\
\hline \multirow{3}{*}{ SPD } & NSCS & 17 & 430.31 & 249.498 & 60.512 & 302.027 & 558.587 & 154.107 & 903.371 \\
\hline & SCS & 11 & 128.22 & 104.489 & 31.505 & 58.026 & 198.420 & 13.112 & 339.835 \\
\hline & Total & 28 & 311.63 & 252.001 & 47.624 & 213.915 & 409.347 & 13.112 & 903.3712 \\
\hline \multirow{3}{*}{ GDPC } & NSCS & 17 & 20142.62 & 9473.724 & 2297.715 & 15271.684 & 25013.563 & 6682.852 & 47232.938 \\
\hline & SCS & 11 & 18146.34 & 3123.642 & 941.813 & 16047.853 & 20244.836 & 13746.249 & 25972.359 \\
\hline & Total & 28 & 19358.37 & 7601.680 & 1436.582 & 16410.747 & 22305.995 & 6682.852 & 47232.938 \\
\hline \multirow{3}{*}{ FB } & NSCS & 17 & -5.18 & 1.468 & .356 & -5.931 & -4.422 & -8.00 & -3.00 \\
\hline & SCS & 11 & -8.63 & 5.186 & 1.564 & -12.109 & -5.142 & -22.00 & -3.00 \\
\hline & Total & 28 & -6.53 & 3.766 & .712 & -7.991 & -5.071 & -22.00 & -3.00 \\
\hline \multirow{3}{*}{ PPD } & NSCS & 17 & .47 & .514 & .125 & .21 & .74 & 0 & 1 \\
\hline & SCS & 11 & .18 & .405 & .122 & -.09 & .45 & 0 & 1 \\
\hline & Total & 28 & .36 & .488 & .092 & .17 & .55 & 0 & 1 \\
\hline \multirow{3}{*}{ BGP } & NSCS & 17 & 28.82 & 18.686 & 4.532 & 19.22 & 38.43 & 2 & 80 \\
\hline & SCS & 11 & 3.64 & 3.828 & 1.154 & 1.06 & 6.21 & 1 & 14 \\
\hline & Total & 28 & 18.93 & 19.216 & 3.631 & 11.48 & 26.38 & 1 & 80 \\
\hline \multirow{3}{*}{ SOR } & NSCS & 17 & 65.77 & 18.074 & 4.383 & 56.476 & 75.062 & 27.43 & 91.08 \\
\hline & SCS & 11 & 24.95 & 20.668 & 6.232 & 11.067 & 38.837 & 6.74 & 66.88 \\
\hline & Total & 28 & 49.73 & 27.639 & 5.223 & 39.017 & 60.451 & 6.74 & 91.08 \\
\hline \multirow{3}{*}{ DTP } & NSCS & 17 & 99.16 & 38.724 & 9.392 & 79.255 & 119.075 & 50.797 & 173.502 \\
\hline & SCS & 11 & 469.94 & 367.965 & 110.946 & 222.741 & 717.146 & 28.790 & 1181.885 \\
\hline & Total & 28 & 244.83 & 291.619 & 55.111 & 131.749 & 357.906 & 28.790 & 1181.885 \\
\hline
\end{tabular}

Sources: Authors' computation from Census 2001, RBI, Planning Commission data. Software used: SPSS

\subsection{Analysis of variance}

The variation in variables across the category of states is examined with help of one way ANOVA method. The results are presented in Table 3. The study observes that 
variation in population density, fiscal balance as percent of GSDP, bargaining power (BGP) across the SCS and NSCS states is significant, but it is not significant for variables like gross domestic product per capita (GDPC), political power dummy (PPD). The variation between in the dependent variable discretionary transfer per capita(DTP) is also tested to be highly significant.

Table 3: ANOVA for the Year 2001

\begin{tabular}{|c|c|c|c|c|c|c|}
\hline & & Sum of Squares & df & Mean Square & $\mathbf{F}$ & Sig. \\
\hline \multirow{3}{*}{ SPD } & Between Groups & 609450.43 & 1 & 609450.438 & 14.338 & .001 \\
\hline & Within Groups & 1105171.66 & 26 & 42506.602 & & \\
\hline & Total & 1714622.10 & 27 & & & \\
\hline \multirow{3}{*}{ GDPC } & Between Groups & 26614967.26 & 1 & 26614967.266 & .451 & .508 \\
\hline & Within Groups & 1533594764.93 & 26 & 58984414.036 & & \\
\hline & Total & 1560209732.19 & 27 & & & \\
\hline \multirow{3}{*}{ FB } & Between Groups & 79.44 & 1 & 79.445 & 6.808 & .015 \\
\hline & Within Groups & 303.38 & 26 & 11.669 & & \\
\hline & Total & 382.83 & 27 & & & \\
\hline \multirow{3}{*}{ PPD } & Between Groups & .55 & 1 & .557 & 2.466 & .128 \\
\hline & Within Groups & 5.87 & 26 & .226 & & \\
\hline & Total & 6.42 & 27 & & & \\
\hline \multirow{3}{*}{ BGP } & Between Groups & 4236.84 & 1 & 4236.841 & 19.215 & .000 \\
\hline & Within Groups & 5733.01 & 26 & 220.501 & & \\
\hline & Total & 9969.85 & 27 & & & \\
\hline \multirow{3}{*}{ SOR } & Between Groups & 11126.55 & 1 & 11126.553 & 30.456 & .000 \\
\hline & Within Groups & 9498.67 & 26 & 365.334 & & \\
\hline & Total & 20625.22 & 27 & & & \\
\hline \multirow{3}{*}{ DTP } & Between Groups & 918148.87 & 1 & 918148.870 & 17.324 & .000 \\
\hline & Within Groups & 1377976.93 & 26 & 52999.113 & & \\
\hline & Total & 2296125.80 & 27 & & & \\
\hline
\end{tabular}

Sources: Same as Table 2

The results in Table 3 show that the variability between special category and nonspecial category states is significant for variables like state population density (SPD), fiscal balance (FB), political bargaining power of the state (BGP), states' own revenue 
10 | VISION: Journal of Indian Taxation, Volume 4, Issue 1, January-June 2017

(SOR), and discretionary transfer per capita (DTP), whereas it is not significant for two variables gross domestic product per capita (GDPC) and political party dummy (PPD).

The similar exercise of comparison of the profiles of SCS and NSCS is attempted for the Census year 2011, and the results are presented in Tables 4-5. We observe similar differences between the SCS and NSCS states in references to the selected variables in 2011 just like 2001. There is a huge gap in population density, bargaining power and state's own share of revenue in the total revenue. So also is the gap in the per capita discretionary transfer between the two categories of states. The SCS gets an average transfer of Rs. 1833 per head as compared to just Rs. 384 in case of NSCS. (Refer Table 4).

Table 4: Profiles of SCS versus NSCS in 2011

\begin{tabular}{|c|c|c|c|c|c|c|c|c|c|}
\hline & \multirow[t]{2}{*}{$\mathbf{N}$} & \multirow[t]{2}{*}{ Mean } & \multirow[t]{2}{*}{$\begin{array}{c}\text { Std. } \\
\text { Deviation }\end{array}$} & \multirow[t]{2}{*}{$\begin{array}{l}\text { Std. } \\
\text { Error }\end{array}$} & \multicolumn{2}{|c|}{$\begin{array}{l}\text { 95\% Confidence } \\
\text { Interval for Mean }\end{array}$} & \multirow[t]{2}{*}{ Minimum } & \multirow[t]{2}{*}{ Maximum } \\
\hline & & & & & & $\begin{array}{l}\text { Lower } \\
\text { Bound }\end{array}$ & $\begin{array}{l}\text { Upper } \\
\text { Bound }\end{array}$ & & \\
\hline \multirow{3}{*}{ SPD } & NSCS & 17 & 500.22 & 290.23 & 70.39 & 351.00 & 649.44 & 189 & 1106 \\
\hline & SCS & 11 & 150.06 & 120.73 & 36.40 & 68.95 & 231.17 & 17 & 398 \\
\hline & Total & 28 & 362.66 & 292.65 & 55.31 & 249.18 & 476.14 & 17 & 1106 \\
\hline \multirow{3}{*}{ GDPC } & NSCS & 17 & 52058.47 & 38631.97 & 9369.63 & 32195.74 & 71921.20 & 13791 & 185425 \\
\hline & SCS & 11 & 46217.54 & 17977.52 & 5420.43 & 34140.08 & 58295.01 & 25268 & 86787 \\
\hline & \begin{tabular}{|l|} 
Total \\
\end{tabular} & 28 & 49763.82 & 31820.46 & 6013.50 & 37425.13 & 62102.51 & 13791 & 185425 \\
\hline \multirow{3}{*}{ FB } & NSCS & 17 & -2.17 & 1.07 & .26 & -2.7289 & -1.6240 & -4.00 & .00 \\
\hline & SCS & 11 & -4.45 & 3.85 & 1.16 & -7.0454 & -1.8637 & -11.00 & 1.00 \\
\hline & Total & 28 & -3.07 & 2.73 & .52 & -4.1317 & -2.0112 & -11.00 & 1.00 \\
\hline \multirow{3}{*}{ PPD } & NSCS & 17 & .41 & .51 & .12 & .15 & .67 & 0 & 1 \\
\hline & SCS & 11 & .64 & .51 & .15 & .30 & .98 & 0 & 1 \\
\hline & Total & 28 & .50 & .51 & .09 & .30 & .70 & 0 & 1 \\
\hline \multirow{3}{*}{ MP } & NSCS & 17 & 28.82 & 18.69 & 4.53 & 19.22 & 38.43 & 2 & 80 \\
\hline & SCS & 11 & 3.64 & 3.83 & 1.15 & 1.06 & 6.21 & 1 & 14 \\
\hline & \begin{tabular}{|l|} 
Total \\
\end{tabular} & 28 & 18.93 & 19.22 & 3.63 & 11.48 & 26.38 & 1 & 80 \\
\hline \multirow{3}{*}{ DTP } & NSCS & 17 & 383.56 & 90.29 & 21.89 & 337.14 & 429.98 & 217 & 579 \\
\hline & SCS & 11 & 1832.53 & 1406.41 & 424.05 & 887.69 & 2777.36 & 467 & 4093 \\
\hline & \begin{tabular}{|l|} 
Total \\
\end{tabular} & 28 & 952.80 & 1121.04 & 211.86 & 518.10 & 1387.49 & 217 & 4093 \\
\hline \multirow{3}{*}{ SOR } & NSCS & 17 & 63.51 & 16.76 & 4.06 & 54.89 & 72.13 & 26.31 & 84.15 \\
\hline & SCS & 11 & 24.97 & 14.43 & 4.35 & 15.28 & 34.67 & 8.64 & 49.31 \\
\hline & \begin{tabular}{|l|} 
Total \\
\end{tabular} & 28 & 48.37 & 24.72 & 4.67 & 38.79 & 57.96 & 8.64 & 84.15 \\
\hline
\end{tabular}


The ANOVA results for the year 2011 are given in Table 5. Just like 2001, the study finds the variation is significant for the chosen variables like state population density (SPD), Fiscal balance as percent of GDP, political bargaining power as represented by the total number of Lok Sabha MPs from the state (BGP), and state's own share in its total revenue (SOR). Quite similarly, variation is not significant for the variables GSDP per capita, and political party dummy(PPD). There are certain NSCS like Bihar and Odisha whose GSDP per capita is smaller than almost all the SCS states. Similarly, in the era of coalition, there is no significant synchrony between the parties ruling at the Centre and states. In case of some states, it is more or less rotation of governments observable in every elections whereas there are also instances of same party ruling in the state for a longer period of time.

Table 5: ANOVA for the Year 2011

\begin{tabular}{|c|c|c|c|c|c|c|}
\hline & & Sum of Squares & df & Mean Square & $\mathbf{F}$ & Sig. \\
\hline & Between Groups & 818869.518 & 1 & 818869.518 & 14.255 & .001 \\
\hline SPD & Within Groups & 1493541.340 & 26 & 57443.898 & & \\
\hline & Total & 2312410.859 & 27 & & & \\
\hline & Between Groups & 227849339.399 & 1 & 227849339.399 & .219 & .644 \\
\hline GDPC & Within Groups & 27110785832.501 & 26 & 1042722532.019 & & \\
\hline & Total & 27338635171.900 & 27 & & & \\
\hline & Between Groups & 34.659 & 1 & 34.659 & 5.390 & .028 \\
\hline FB & Within Groups & 167.198 & 26 & 6.431 & & \\
\hline & Total & 201.857 & 27 & & & \\
\hline & Between Groups & .337 & 1 & .337 & 1.315 & .262 \\
\hline PPD & Within Groups & 6.663 & 26 & .256 & & \\
\hline & \begin{tabular}{|l|} 
Total \\
\end{tabular} & 7.000 & 27 & & & \\
\hline & Between Groups & 4236.841 & 1 & 4236.841 & 19.215 & .000 \\
\hline $\mathrm{BGP}$ & Within Groups & 5733.016 & 26 & 220.501 & & \\
\hline DUP & Total & 9969.857 & 27 & & & \\
\hline & Total & 281075701237.395 & 27 & & & \\
\hline & Between Groups & 9919.116 & 1 & 9919.116 & 39.225 & .000 \\
\hline SOR & Within Groups & 6574.742 & 26 & 252.875 & & \\
\hline & Total & 16493.858 & 27 & & & \\
\hline & Between Groups & 14021631.540 & 1 & 14021631.540 & 18.310 & .000 \\
\hline DTP & Within Groups & 19910241.583 & 26 & 765778.522 & & \\
\hline & Total & 33931873.123 & 27 & & & \\
\hline
\end{tabular}

Source: Same as Table 2 
More often than not, some political parties also change their alignments from election to election. This phenomenon is more or less similar across SCSs and NSCSs. Thus variation across state categories is not significant for the variable PPD. However, the study finds the variation in discretionary transfers per capita as highly significant for the SCS and NSCS categories of states.

From Table 5, it is understood that except for GDPC and PPD, the difference between the two groups SCS and NSCS for all other variables including discretionary transfer per capita (DTP) are significant. The analysis so far is in relation to the differences between the groups SCS and NSCS. We have made a further attempt to analyse how far the discretionary transfer to individual states has undergone change between the two study years.

Figures 2 and 3 show how have discretionary transfers per capita changed for SCS and NSCS states between 2001 and 2011. Among the special category states, the north-eastern states except Assam have got the highest transfer per capita. The biggest beneficiaries are Arunachal Pradesh, Sikkim and Mizoram. On the contrary, some other states likeUttarakhand, Himachal Pradesh and J\&K have not received that much of transfer. In 2011, Arunachal Pradesh received ₹ 4092, whereas Uttarakhand received just ₹ 467 per capita. It is noteworthy that the national average of discretionary transfers to all states per capita is ₹ 953. So there are some states in SCS category which are receiving less DTP than some NSCS counterparts. Apart from their geopolitical situations what else is determining this difference is a matter of further scrutiny.

Figure 2: Discretionary TransfersPer Capita between 2001 and 2011 for SCS

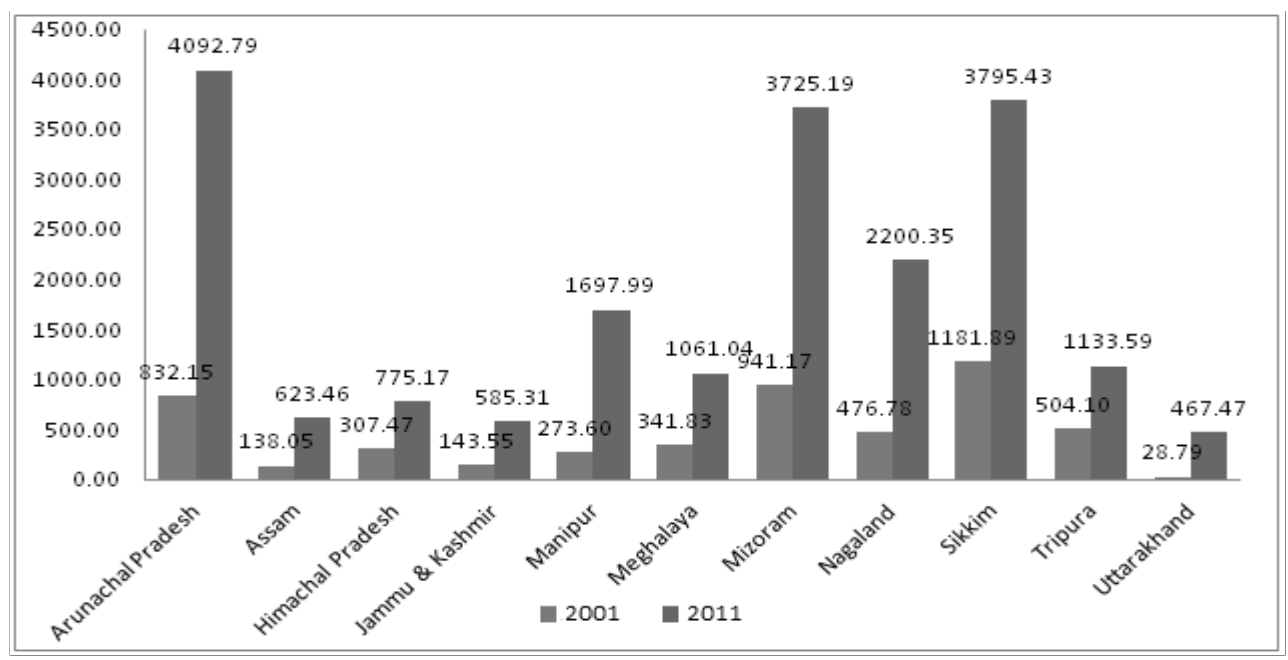

Source: Compiled from State Finances-A study of budget, RBI; and Census of India-2001\&2011. 
Figure 3: Discretionary Transfer Per Capita between 20012011 for NSCS

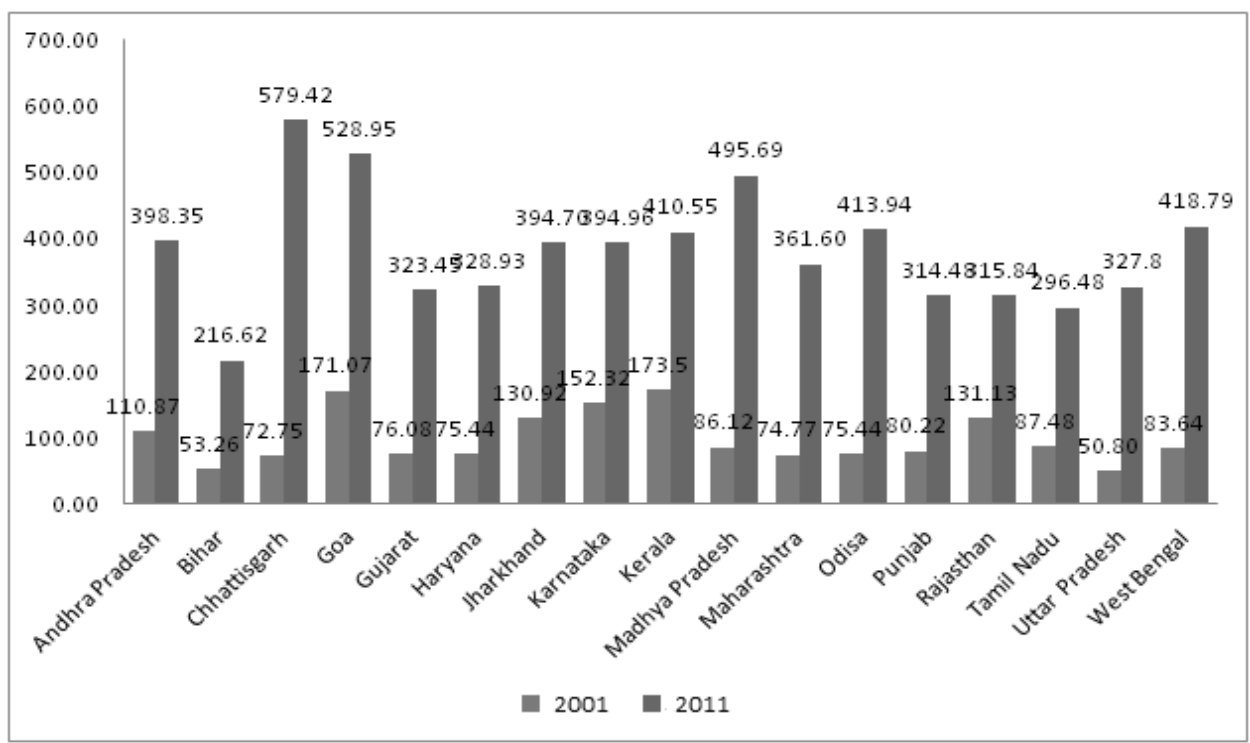

Source: Same as Figure 2.

Unlike some of the SCSs, not a single NSCS has received DTP of magnitude higher than Rs. 1000. As far as increase in DTP is concerned states like Chhattisgarh and Madhya Pradesh, Odisha and West Bengal seem to be the biggest beneficiaries, whereas southern states like Karnataka and Kerala have not experienced that much rise in DTP during 2001-11. It is observable that Kerala was ruled by the same political party/coalition which was ruling at the Centre in 2011, whereas Madhya Pradesh, Chhattisgarh, and Odisha were ruled by the opposition parties at the states. So politicalbias in allocation of DTP seems to be exaggerated at this moment. So this study does not corroborate the findings of Arulampalam et al. (2009), Biswas et al. (2009) and Dash and Raja (2012) that political determinants have significant role in the disbursement of discretionary transfers. However, the regression results will give a clearer picture of this argument.

\subsection{Regression results}

We have used the technique of regression through backward elimination for selection of relevant regressors for discretionary transfer per capita (DTP). The final selection is done by taking into consideration the values of adjusted $\mathrm{R}^{2}$. Interestingly, regression through backward elimination gives the same two regressors for both the 
years 2001 and 2011 (Table 6 and 7). The adjustedR ${ }^{2}$ is the highest in Model 4 in both the tables. The $\mathrm{R}^{2}$ values indicate that $54 \%$ (2001) and $58 \%$ (2011) of variation in discretionary transfer per capita to a state are explained by two factors by the regression for 2001 and 2011 respectively. The d-statistics, and TOL coefficients also show that the models are not facing any autocorrelation or multicollinearity problems.

Table 6: Model Summary of Backward Regressionfor 2001

\begin{tabular}{|c|c|c|c|c|}
\hline Model & $\mathbf{R}$ & $\mathbf{R}^{\mathbf{2}}$ & Adj. $\mathbf{R}^{\mathbf{2}}$ & SEE \\
\hline 1 & $.751^{\text {a }}$ & .564 & .465 & 213.378 \\
\hline 2 & $.749^{\mathrm{b}}$ & .561 & .484 & 209.420 \\
\hline 3 & $.741^{\text {c }}$ & .549 & .493 & 207.716 \\
\hline $\mathbf{4}$ & $\mathbf{. 7 3 5}^{\text {d }}$ & $\mathbf{. 5 4 0}$ & $\mathbf{. 5 0 4}$ & $\mathbf{2 0 5 . 4 6 0}$ \\
\hline
\end{tabular}

a. Predictors: (Constant), CAT, GDPC, PPD, FB, BGP

b. Predictors: (Constant), CAT, GDPC, PPD, FB

c. Predictors: (Constant), CAT, GDPC, FB

d. Predictors: (Constant), CAT, FB

Dependent Variable: DTP

Table 7: Model Summaryof Backward Regression for 2011

\begin{tabular}{|c|c|c|c|c|}
\hline Model & $\mathbf{R}$ & $\mathbf{R}^{\mathbf{2}}$ & Adj. $^{\mathbf{2}}$ & SEE \\
\hline 1 & $.765^{\mathrm{a}}$ & .586 & .492 & 799.101 \\
\hline 2 & $.765^{\mathrm{b}}$ & .586 & .514 & 781.639 \\
\hline 3 & $.765^{\mathrm{c}}$ & .585 & .533 & 766.348 \\
\hline $\mathbf{4}$ & $\mathbf{. 7 6 1}^{\mathrm{d}}$ & $\mathbf{. 5 8 0}$ & $\mathbf{. 5 4 6}$ & $\mathbf{7 5 5 . 4 2 3}$ \\
\hline
\end{tabular}

a. Predictors: (Constant), CAT, GDPC, PPD, FB, BGP

b. Predictors: (Constant), CAT, GDPC, FB, BGP

c. Predictors: (Constant), CAT, GDPC, FB

d. Predictors: (Constant), CAT, FB

Dependent Variable: DTP

The regression coefficients are presented in Table 8 . The study finds that only two regressors viz. fiscal balance as percentage of GSDP of a state, and the category of states are the most important determinants of discretionary transfers to a state. It is important to notice the signs of the regression coefficients too. The coefficient in relation to the fiscal balance of the state as percentage of GSDP (FB) has negative sign, whereas the regression coefficient with respect to category of the state has positive sign for both the years of study. Thus this may be considered as a robust finding that it is not the political factors but the fiscal requirement of the states along with its eligibility as 
defined by the category of the state- SCS or NSCS- determine the discretionary transfers. If a state has larger fiscal deficit, discretionary transfer has been higher than otherwise. The statement that governments becoming prejudicial in allocating discretionary transfers are not substantiated.

Table 8: Regression Coefficients 2001 and 2011

\begin{tabular}{|c|c|c|c|c|c|c|c|c|}
\hline \multirow{3}{*}{ Regressor } & \multicolumn{4}{|c|}{2001} & \multicolumn{4}{|c|}{2011} \\
\hline & \multicolumn{2}{|c|}{$\begin{array}{l}\text { Unstandardized } \\
\text { Coefficients }\end{array}$} & \multirow[t]{2}{*}{$\mathbf{t}$} & \multirow[t]{2}{*}{ Sig. } & \multicolumn{2}{|c|}{$\begin{array}{l}\text { Unstandardized } \\
\text { Coefficients }\end{array}$} & \multirow[t]{2}{*}{$\mathbf{T}$} & \multirow[t]{2}{*}{ Sig. } \\
\hline & B & $\begin{array}{l}\text { Std. } \\
\text { Error }\end{array}$ & & & B & $\begin{array}{l}\text { Std. } \\
\text { Error }\end{array}$ & & \\
\hline (Constant) & -69.642 & 78.814 & -.884 & .385 & -16.306 & 223.017 & -.073 & .942 \\
\hline FB & -32.610 & 11.796 & 2.765 & .011 & -183.723 & 58.422 & $3.145^{-}$ & .004 \\
\hline CAT & 258.306 & 89.308 & 2.892 & .008 & 1030.429 & 321.185 & 3.208 & .004 \\
\hline $\mathrm{R}^{2}$ & \multicolumn{3}{|c|}{0.540} & .000 & \multicolumn{3}{|c|}{0.580} & .000 \\
\hline Adj. $\mathrm{R}^{2}$ & \multicolumn{3}{|c|}{0.504} & & \multicolumn{3}{|c|}{0.546} & \\
\hline $\mathrm{F}$ & \multicolumn{3}{|c|}{14.696} & .000 & \multicolumn{3}{|c|}{17.23} & .00 \\
\hline $\mathrm{D}$ & \multicolumn{3}{|c|}{1.815} & & \multicolumn{3}{|c|}{1.861} & \\
\hline
\end{tabular}

Source: Authors' computation by using software SPSS

\subsection{Summary and Conclusion}

This paper makes an attempt to focus on some new dimension of federal fiscal transfer motivated from political economy prospective. Our motivation was to assess if federal system in India is a constitutional or a political bargain process. Even though India was not formed out of an explicit bargaining process, the perspective of bargaining is commonly applied informally to resource sharing among the different constituent governments. The political determinants which we have taken for this paper do not have any significant impact on per capita discretionary transfer. But the literature on Centre state discretionary grant shows that political factors have some significance for pulling central grants towards sub central units particularly during the era of coalition politics. The present study, however, observes that states with larger fiscal requirement receive more Central discretionary transfers, and another important factor determining discretionary transfer is the category of the state.

The paper analysed the differences of the characteristics between SCS and NSCS states through an ANOVA analysis. It found that SCS and NSCS states differ significantly in relation to population density, fiscal balance, and political bargaining 
power. Higher fiscal deficits of the SCS states might be driven by continual expectation revisions that they will get further funds once they spend a lot and show a deficit. The study observed that SCS and NSCS states do not differ in per capita GSDP and political alignments. These two factors are also not found to be statistical insignificant in influencing discretionary transfers.

This analysis brings out our main concerns with the transfer system developed in India. It is not that the system has failed to offset the fiscal disadvantages of poorer states entirely; rather, the design and the methodology of transfers raise serious doubts about objectivity, simplicity and fairness. Probably there is no system in the world that achieves perfect equalization, even if such a system were to be desired by economists. The degree of equalization achieved in a federation will be determined according to a compromise among rival parties. However, certainly, it should be possible to channel the transfers through a single, permanent, professional agency; it should be possible to have a rule-based system of transfers instead of expanding central discretion; it should be possible to design the transfer system with appropriate incentives for the Centre and the states; and it should be possible to minimize regional transfers arising from undesirable policies (such as inter-state sales taxes) or at least identify the effect of these implicit transfers.

Criticism of the system of intergovernmental transfers in India should not detract from its achievements. The very fact that the system has survived for over more than 60 years in a country despite diversity in economic, political, linguistic and cultural factors implies the broad acceptability of the basic structure and functioning of the federation. The method of resolving the problems of special category states, the introduction of formula-based transfers in place of discretionary transfers, achieving a measure of equalization through formula-based transfers, and the attempt to reach consensus solutions to many contentious issues are some of the positive features. Although our analysis does not rebuff the necessity of reforms in federal fiscal transfers, it is not cynical against the viewpoint of discretionary transfers as a channel of Centre-state fiscal transfer in India.

\section{Endnotes}

1. The Planning Commission has been rechristened as National Institution for Transforming India (NITI) Aayog and it has been entrusted to prepare a 15 Year Vision document beginning 2017-18, which will replace Nehruvian Five Year planning system followed for over six decades. Besides the vision, the Aayog would be ready with seven year strategy and 
three year action plan on the basis of which funds allocations will be made in the budget.(The Economic Times, 20 July 2016).

2. There is, however, no unanimity among researchers about what actually is a discretionary transfers. In a democracy, a plan is formulated with due constitutional procedure after due approval of the Cabinet. Each plan is made with a view to address some felt needs. But this paper has considered all transfers which are not based on the Finance Commission recommendations, except for Normal Central Assistance, as discretionary. Panda(2016) has also taken a similar approach. The authors also acknowledge the discussion with M. Govinda Rao, Emeritus Professor, NIPFP, New Delhi on this definitional issue with usual disclaimer.

\section{References}

Arulampalam, W., Dhillon, A., Dasgupta, S., \& Bhaskar, D. (2009). Electoral goals and Centre state transfers: A theoretical model and empirical evidence from India. The Journal of Development Economics, 88(1), 103-119.

Biswas, R., Marjit, S., \& Marimoutou, V. (2009). Fiscal federalism, state lobbying and discretionary finance: Evidencefrom India. Economics and Politics, 22(1), 68-91.

Buchanan, J. (1950). Federalism and fiscal equity. American Economic Review, 40(4), 583-99.

Dasgupta, S., Dhillon, A., \& Dutta, B. (2004). Electoral goals and centre-state transfers: A theoretical model and empirical evidence from India. Retrieved from http://citeseerx. ist.psu.edu/viewdoc/download?doi=10.1.1.471.839\&rep=rep1\&type=pdf

Dash, B.B., \& Raja, A. (2012). Political determinants of the allocation of public expenditures: A study of the Indian states. NIPFP Working Paper No. 2012-101, New Delhi.

Dixit, A., \& Londregan, J. (1996).The determinants of success of special interests in redistributive politics. The Journal of Politics, 58(4), 1132-1155.

ET Bureau (2016, July 20). Niti Aayog may tell states to align with centre's vision. The Economic Times, p.15, Delhi. 
Gramlich, E.M. (1977). Intergovernmental grants: A review of the empirical literature. In W. E. Oates (Ed.). The Political Economy of Fiscal Federalism, pp. 219-240. Lexington: Lexington Books, D.C. Heath and Company.

Khemani, S. (2003). Partisan politics and intergovernmental transfers in India. Development Research Group Working Paper No. 3016, The World Bank.

Lindbeck, A., \& Weibull, J. (1987).Balanced budget redistribution as the outcome of political competition. Public Choice, 52(3), 273-297.

Oates, W. (1972). Fiscal federalism. New York, NY: Harcourt-Brace-Jovanovich.

Panda, P.K. (2016). Economic and political determinants of central fiscal transfer in India: A dynamic panel analysis of state level data. The Journal of Developing Areas, 50(2), 329-347.

Rao, M. G., \& Singh, N. (2000). The political economy of centre-state fiscal transfers in India. Paper presented at the Columbia University- World Bank Conference on Institutional Elements of Tax Design and Reform, February 18-19, New York: Columbia University.

Riker, W. (1975). Federalism. In F. I. Greenstein and N. W. Polsby, (Eds.). Handbook of political science. (pp. 75-85). Massachusetts: Addison-Wesley.

Singh, N., \& Vasishtha, G. (2004). Some patterns in centre-state fiscal transfers in India: An illustrative analysis. SSCIE Working Paper No. 4-18, Santa Cruz Centre for International Economics: University of California. 